\title{
INOVAÇÕES NO ATENDIMENTO DO CLIENTE NO SERVIÇO DE HEMODINÂMICA
}

\section{INTRODUÇÃO}

Empatia é a habilidade de se colocar no lugar da pessoa a fim de compreender na mesma perspectiva as experiências vivenciadas pelo outro. Profissionais que estabelecem relações empáticas durante a assistência prestada impactam diretamente na percepção do cliente quanto à qualidade da assistência. Frente à essa perspectiva, estabeleceu-se o acolhimento do cliente no Serviço de Hemodinâmica, fortalecendo o vínculo enfermeiro-cliente durante 0 atendimento no procedimento de Angiografia Coronária, assim como o monitoramento de complicações. tardias.

\section{OBJETIVO}

Aumentar a satisfação do cliente atendido no serviço e monitorar os seus eventos adversos.

\section{METODOLOGIA}

Trata-se de um relato de experiência vivenciado durante processo de melhoria no Serviço de Hemodinâmica de uma instituição privada no Noroeste Paulista.

\section{RESULTADOS}

O acolhimento pelo profissional enfermeiro foi determinante para a eficácia das informações colhidas e a busca da resolutividade dos anseios do cliente.
O vínculo estabelecido favoreceu a satisfação do cliente, atingindo o percentual de $100 \%$ durante meses consecutivos, assim como o contato telefônico pós atendimento foi interpretado pelo paciente que o serviço está preocupado com a sua recuperação e bem-estar. Além disso, as informações levantadas durante a abordagem telefônica auxiliaram na monitorização de eventos adversos.

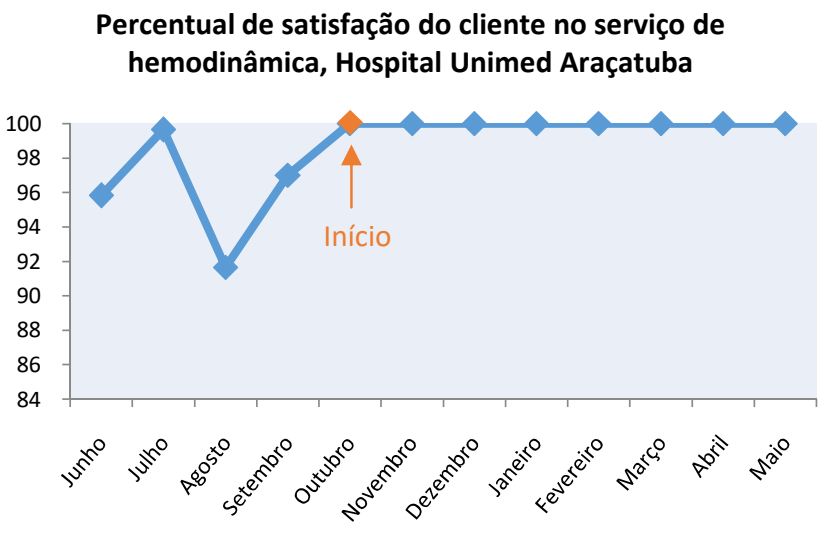

\section{CONCLUSÃO}

O acolhimento e o contato telefônico pós Angiografia Coronária trazem benefícios tanto para o cliente quanto para a instituição. Para o cliente ele se traduz em segurança, apoio e afeto e para o serviço representa a compreensão do indicador de resultado que aponta aos gestores alguns caminhos decisórios de transformações e inovações.

REFERÊNCIAS: 1-Freitas JS, Silva AEBC, Minamisava R, Bezerra ALQ, Sousa MRGS. Qualidade dos cuidados de enfermagem e satisfação do paciente atendido em um hospital de ensino. Rev. Latino-Am. Enfermagem. 2014;22(3):454-60. 2-Terezam R, Reis-Queiroz J, Hoga LAK. A importância da empatia no cuidado em saúde e enfermagem. Rev. Bras. Enferm. 2017;70(3):697-8 